\title{
Viva Las Vegas
}

\author{
Bridget Russo
}

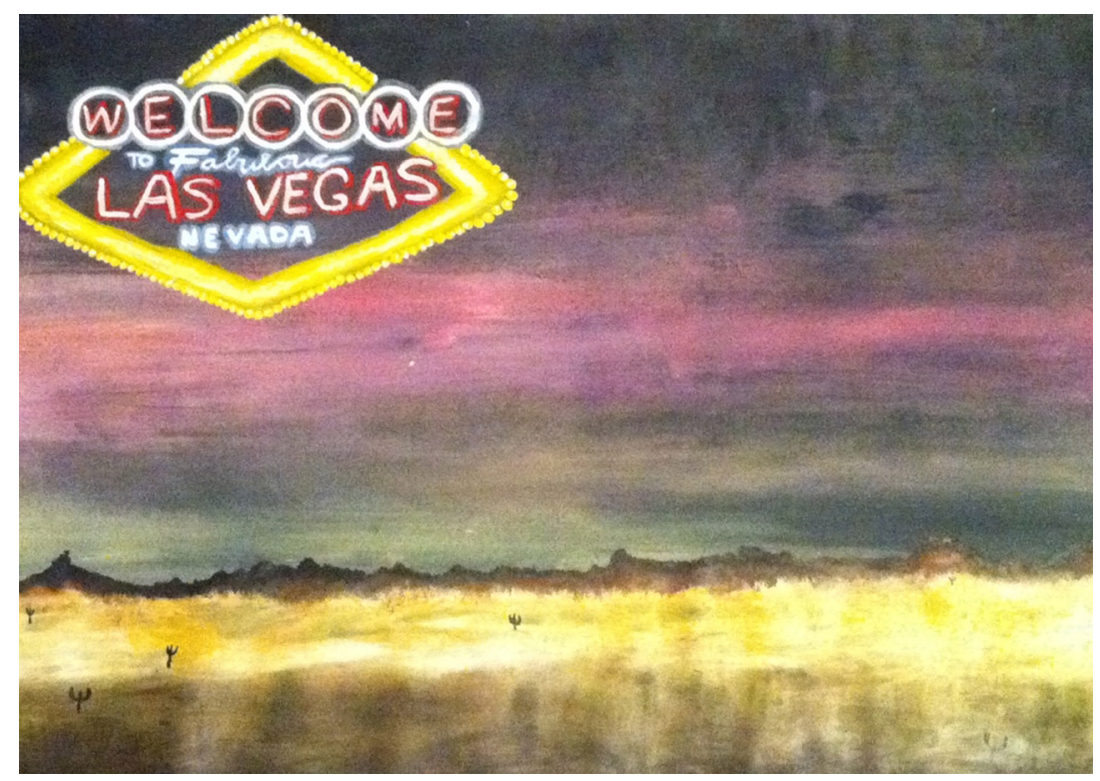

\begin{tabular}{l|l} 
Offset no. 11 & 47
\end{tabular} 